\title{
A DITADURA E OS RASTROS DA REPRESSÃO NO SUDESTE PARAENSE: DESVELANDO MEMÓRIAS SOBRE A CASA AZUL
}

\author{
Janailson Macêdo Luiz ${ }^{1}$ \\ Naurinete Fernandes Inácio Reis ${ }^{2}$ \\ Idelma Santiago da Silva
}

A Guerrilha do Araguaia (1972-1974) é um dos temas da história recente do Brasil que, a despeito de todo o silenciamento que ainda o cerca, com mais frequência tem sido objeto de produções acadêmicas e, em maior número, não acadêmicas, seja por meio do desenvolvimento de teses, dissertações, monografias e artigos; seja a partir da elaboração de documentários, publicações em revistas e jornais, peças de teatro e outras produções culturais divulgadas nos mais diversos formatos.

Todavia, apesar do grande quantitativo de produções, muitos episódios e elementos do contexto relacionado a esse conflito ainda merecem maior aprofundamento no âmbito acadêmico, a partir de análises críticas elaboradas com base em um criterioso cruzamento de informações, $e$ alicerçada por um aparato teórico-metodológico que permita reflexões que não se limitem a meras polarizações ou defesas apaixonadas de um determinado grupo.

Este artigo objetiva, na esteira do que é dito acima, apresentar resultados de pesquisa voltados para um dos locais ainda pouco estudados academicamente que possibilitam a construção de diversas significações acerca da Guerrilha e do período em que ela ocorrera. Debruça-se, desse modo, sobre a Casa Azul, espaço que conjuntamente com a chamada Casa da Morte, ${ }^{4}$ em Petrópolis, e o DOI-Codi, ${ }^{5}$ em São Paulo, é apontado como uma das instalações onde foi colocada em prática uma série de violações contra os direitos humanos durante a Ditadura Militar no Brasil (1964-1985).

No relatório final da Comissão Nacional da Verdade (CNV), produzido em 2014, a Casa Azul é definida da seguinte maneira:

Centro de prisão clandestino utilizado pelo Centro de Informações do Exército (CIE) como um Centro de Informações e Triagem (CIT). No local, estima-se que morreram, em decorrência de tortura ou por execução, mais de 30 guerrilheiros que faziam oposição ao regime militar e que atuavam na Guerrilha do Araguaia. Os principais alvos eram militantes do PCdoB e moradores locais acusados de apoiar a guerrilha. ${ }^{6}$

\footnotetext{
${ }^{1}$ Professor da Faculdade História, Campus Marabá, da Universidade Federal do Sul e Sudeste do Pará (UNIFESSPA). Mestre em História pela Universidade Federal de Campina Grande (UFCG) e Doutorando do Programa de Pós-Graduação em História Social da Universidade de São Paulo (PPGHS/USP). E-mail: janailson@unifesspa.edu.br

${ }^{2}$ Mestra em Sociologia pela Universidade Federal de Goiás (UFG). Doutoranda do Programa de Geografia Humana da Universidade de São Paulo (PPGH/USP) e servidora efetiva (TAE) da Unifesspa. E-mail: neteinacio@unifesspa.edu.br.

${ }^{3}$ Doutora em História pela UFG. Professora Adjunta lotada na Faculdade de Educação do Campo e no Programa de PósGraduação em Dinâmicas Territoriais e Sociedade na Amazônia (PDTSA) da Unifesspa. E-mail: idelma@unifesspa.edu.br.

${ }^{4}$ Conforme fora apresentado em relatório preliminar da CNV, em 2014: "A Casa da Morte foi uma estrutura criada pelo Centro de Informações do Exército (CIE), no início do ano de 1971, para atender a uma nova estratégia de intensificação do combate às organizações armadas de esquerda pela ditadura. Nessa nova etapas, o aparelho repressivo passou a contar com bases secretas e equipes especializadas na execução de uma política de extermínio e desaparecimento forçado das principais lideranças das organizações em luta aberta contra o regime ditatorial". In: BRASIL. COMISSÃO NACIONAL DA VERDADE. Relatório preliminar de pesquisa sobre a "Casa da Morte de Petrópolis": Volume I. Brasília: CNV, 2014. p. 5.

${ }^{5}$ Sobre o DOI-Codi, Godoy destaca que: "Símbolo do Arbítrio e dos crimes de um regime, o Destacamento de Operações de Informações (DOI) ganhou de seus integrantes um codinome. Chamavam-no de Casa da Vovó. Ali militares e policiais trabalharam lado a lado durante os anos que muitos deles consideravam memoráveis (...) Criada em São Paulo, seu modelo se espalhou pelo País. (...) Até hoje muitos dos que trabalharam lá preferem chamá-la de Casa da Vovó, pois, como explicou um de seus agentes, 'lá é que era bom'. A antinomia era evidente. Ainda mais quando esses homens e mulheres resolveram contar o que sabiam sobre as mortes de 66 pessoas, das quais 39 sob tortura após a prisão e outras 27 depois de gravemente baleadas durante a detenção no que foi descrito como emboscadas ou tiroteios". GODOY, Marcelo. A Casa da Vovó: Uma biografia do DOI-Codi (1969-1991), o centro de sequestro, tortura e morte da ditadura militar. São Paulo: Alameda, 2014. p. 20.

${ }^{6}$ BRASIL. Comissão Nacional da Verdade. Relatório: Volume I. Brasília: CNV, 2014, p. 793.
} 
Oficialmente, a Casa Azul era a sede do Departamento Nacional de Estradas de Rodagem (DNER), órgão fundamental no contexto de construção da Transamazônica, rodovia que representava a espinha dorsal para o Plano de Integração Nacional (PIN) de 1970. Atualmente, as instalações, que margeiam a referida rodovia, em Marabá-PA, são ocupadas pelo Departamento Nacional de Infraestrutura de Transportes (DNIT), e ainda se mantêm de pé alguns dos espaços que foram utilizadas pelo CIE, com destaque para o prédio descrito como espaço de tortura, tanto por ex-militares que ali serviram, como por camponeses que ali estiveram presos clandestinamente.

No começo dos anos 1970, quem atravessava o rio Itacaiúnas, de barco, rumo ao local onde, atualmente, encontra-se o núcleo populacional Cidade Nova (um dos três que formam Marabá), logo se deparava com uma casa de cor azul, próxima à margem do rio. Não tardou pra que todo o espaço do órgão passasse a ser conhecido por muitos como Casa Azul, onde se inclui a casa em "L" apontada como lugar central das torturas, apesar de essas também serem aplicadas, segundo diversas testemunhas, em outros espaços da instalação, incluindo-se os locais externos.

Não é simples o acesso a fontes referentes a um lugar que, oficialmente, não existira; ou que apenas recentemente se consolidou na memória tida sobre a Guerrilha, principalmente após a publicação do relatório final da $\mathrm{CNV}$, em 2014. Todavia, e justamente por isso, faz-se relevante colocar em prática um dever de memória em que seja possível buscar compreensões sobre esse espaço a partir dos rastros $^{7}$ que foram deixados, e das memórias difíceis relacionadas à Guerrilha; memórias e rastros que remetem a algo que não apenas não existe mais, mas que fora alvo de estratégias diversas que buscaram o seu apagamento frente às gerações futuras.

O historiador Rodrigo Patto Sá Motta chega mesmo a defender que, em contextos de transição democrática, efetuados após períodos ditatoriais, como vivido no Brasil há três décadas, o conhecimento histórico e o ofício do historiador sejam acionados em auxílio a um dever de memória. Isso possibilita a efetuação de um dever da história ${ }^{8}$ em que, para além das disputas entre projetos de memória, sejam inseridas análises a partir dos referenciais próprios do ofício de historiador, considerando-se que o conhecimento histórico pode promover a decisiva inserção de uma discussão crítica no debate público sobre tais períodos.

Com esse objetivo, na pesquisa que resultou o trabalho aqui em discussão, elaborada inicialmente num grupo de trabalho constituído pelos autores e organizado no âmbito da Unifesspa ${ }^{9}$, foram buscadas informações sobre a Casa Azul presentes em fontes diversas, tais como publicações que tratam da Guerrilha e de outros episódios relativos ao período na região; publicações produzidas sobre a Guerrilha em jornais impressos (a exemplo de O Globo e da Folha de São Paulo), revistas e outras publicações jornalísticas ou acadêmicas; publicações de militares da reserva que atuaram na Casa Azul, bem como relatos produzidos por camponeses que estiveram presos ou transitaram por aquele local $e$ ex-militares e militares da reserva que ali serviram.

Boa parte desses depoimentos foi dada a comissões como a CNV, documentários ou, ainda, a grupos de trabalho, a exemplo do Grupo de Trabalho Tocantins (GTT) e do GT Araguaia (GTA) -

\footnotetext{
${ }^{7}$ Segundo Gagnebin, o "conceito de rastro nos conduz à problemática, brevemente evocado, da memória. Notamos primeiro que o rastro, na tradição filosófica e psicológica, foi sempre uma dessas noções preciosas e complexas - para não dizer, em boa (?) lógica cartesiana, obscuras - que procuram manter juntas a presença do ausente e a ausência da presença. Que seja sobre tabletes de cera ou sobre um bloco mágico, essas metáforas privilegiadas da alma, o rastro inscreve a lembrança de uma presença que não existe mais e que sempre corre o risco de apagar definitivamente". GAGNEGIN, Jeanne Marie. Verdade e memória do passado. Projeto História, São Paulo, n. 17, p. 213-221, nov. 1998, p. 213. Sobre algumas formas como no tempo presente tem sido abordadas as memórias difíceis legadas pelas Ditadura do Cone-Sul, ver NEVES, Deborah Regina Leal. A persistência do passado: patrimônio e memoriais da ditadura em São Paulo e Buenos Aires. 2014. 255f. Dissertação (Mestrado em História) - Universidade de São Paulo, São Paulo, 2014.

${ }^{8}$ Motta defende um papel ativo dos historiadores nos debates e ações voltadas para o dever de memória em contextos pósautoritários. Para aquele historiador: "Assim como se fala em dever de memória, poderíamos falar em dever da História. Os historiadores deveriam investir mais neste terreno, oferecendo seu olhar e perspectiva característicos, e também estimular a formação de novos pesquisadores que se dediquem ao passado recente, tanto por razões acadêmicas quanto cívicas". In: MOTTA, Rodrigo Patto Sá. História, Memória e as disputas pela representação do passado recente. Patrimônio e Memória (Unesp), v. 9, p. 56-70, 2013. p. 64.

${ }^{9} \mathrm{O}$ grupo fora instituído em 2015 pela reitoria e elaborou relatório interno acerca do valor histórico-cultural do espaço ferido neste artigo, visando levantar informações para posterior pedido de tombamento do local. Além dos autores do artigo, também integrou o grupo de trabalho o docente de Geologia, Prof. Dr. Antônio Emídio de Araújo Santos Júnior. Ver: LUIZ, Janailson Macêdo; REIS, Naurinete Inácio Fernandes dos; SANTOS JUNIOR, Ângelo Emídio de Araújo Santos; SILVA, Idelma Santiago da. Relatório preliminar: valor histórico cultural da Casa Azul. Marabá: Unifesspa, 2017.
} 
instituídos pelo Governo Federal - que, nas últimas duas décadas, tiveram a incumbência de tentar localizar os restos mortais dos guerrilheiros na região. Apesar de tais ações, a grande maioria dos corpos ainda não foi localizada, mesmo passadas quase cinco décadas do início dos conflitos e das primeiras mortes e desaparecimentos.

Quanto à busca documental, não é demais relembrar a não abertura, pelas Forças Armadas, da maior parte dos documentos oficiais relacionados ao trabalho do CIE e das demais instâncias militares durante o combate aos guerrilheiros, assim como ocorre em relação à boa parte do conjunto de documentos produzidos durante todo o período ditatorial. Apesar dos documentos que já foram localizados sobre a atuação da Ditadura, ainda são muitos os episódios em que o acesso de documentos oficiais não ocorrera.

A ausência de tal acesso, certamente, limita bastante a pesquisa histórica e o cumprimento do direito à memória, tido pela população brasileira sobre os eventos ocorridos na Ditadura. Contudo, acaba servindo de estímulo para a manutenção do silenciamento quanto aos abusos aos direitos humanos e à violação impetrada por parte do Estado brasileiro entre 1964 e 1985. Na região do Araguaia, tais abusos ganharam contorno de lei durante o período da Guerrilha e nos anos que se seguiram - período em que, para muitos pesquisadores, iniciou-se a "guerra que veio depois"10 - dada a grande quantidade de conflitos, assassinatos de lideranças políticas e massacres ocorridos, bem como a continuidade de vigilância sobre os movimentos sociais, especialmente aqueles voltados para a luta pela terra, como o Movimento dos Trabalhadores Rurais Sem Terra (MST) e os sindicatos rurais. ${ }^{11}$

Nesse sentido, abordar a importância histórica da Casa Azul se constitui como um exercício que converge com o proposto por Benjamim ${ }^{12}$. Mostra-se, desse modo, necessário que a história da Guerrilha seja narrada a contrapelo, devendo ser buscados os rastros que possibilitem a constituição de narrativas sobre os acontecimentos exumados a contragosto do que fora planejado por instituições $e$ agentes que nele estiveram envolvidos.

A necessidade de exumação ficou mais visível a partir da condenação internacional do Brasil, em 2010, pela Corte Interamericana de Direitos Humanos, no caso Gomes Lund e outros ("Guerrilha do Araguaia") versus Brasil, quando o País fora condenado, entre outras medidas, a: investigar penalmente os fatos relacionados à Guerrilha, responsabilizar penalmente os praticantes; realizar o máximo de esforços no sentido de determinar o paradeiro das vítimas, as condições das mortes $e$ a entrega dos restos mortais às famílias; e continuar as iniciativas de busca, sistematização e publicação de todas as informações a respeito do conflito e das violações de direitos humanos ocorridas em todo o período militar, garantindo aos familiares e à população o acesso a essas informações. ${ }^{13}$

Nas próximas páginas, será apresentada uma breve contextualização de Marabá no período da Guerrilha. Essa contextualização servirá de base para uma melhor compreensão, na sequência, do papel da reconstituição das memórias difíceis após a chamada "Operação limpeza", como é designada pela literatura especializada a ação de apagamento de rastros atribuída aos militares pós 1975, momento em que teriam sido eliminados os restos mortais dos guerrilheiros enterrados em espaços utilizados pelas Forças Armadas, e eliminados documentos alusivos à Guerrilha como um todo.

\section{Marabá e a Guerrilha do Araguaia}

Inicialmente, a Guerrilha opôs os militantes do Partido Comunista do Brasil (PCdoB) e as Forças Armadas, e, cada vez mais, provocou o envolvimento direto e indireto dos moradores da região Sul $e$ Sudeste do Pará, Norte de Tocantins (antigo norte de Goiás) e parte do Maranhão, uma região que era conhecida como Bico do Papagaio, marcada pelo encontro dos rios Araguaia e Tocantins.

\footnotetext{
${ }^{10}$ PEIXOTO, Rodrigo Corrêa Diniz. Memória social da Guerrilha do Araguaia e da guerra que veio depois. Bol. Mus. Para. Emílio Goeldi. Cienc. Hum, Belém, v. 6, n. 3, p. 479-499, set.-dez. 2011.

${ }^{11}$ PETIT, Pere. Chão de promessas: elites políticas e transformações econômicas no estado do Pará pós-1964. Belém: PakaTatu, 2003; PEREIRA, Airton dos Reis. Do posseiro ao sem-terra: A luta pela terra no sul e sudeste do Pará. Recife: Editora UFPE, 2015.

${ }^{12}$ BENJAMIM, Walter. Obras escolhidas, v. I: magia e técnica, arte e política. São Paulo: Brasiliense, 1985.

${ }^{13}$ CORTE INTERAMERICANA DE DERECHOS HUMANOS. Corte IDH. Caso Gomes Lund y otros ("Guerrilha do Araguaia") Vs. Brasil. Excepciones Preliminares, Fondo, Reparaciones y Costas. Sentencia de 24 de noviembre de 2010. Serie C No. 219. Disponível em: http://www.corteidh.or.cr/cf/Jurisprudencia2/busqueda casos contenciosos.cfm?lang=es. Acesso: abr. 2017.
} 
Após serem descobertos, os cerca de 70 militantes do $\mathrm{PCdoB}$, partido que atuava na clandestinidade e adotara uma linha maoísta, optaram, junto com alguns poucos moradores locais, por migrarem para o interior da mata e colocarem em prática um projeto de luta armada para o qual estavam em início de preparação.

Esse projeto teve base na organização de três destacamentos e de uma comissão militar. Entre a população, passaram a ser conhecidos não mais como "paulistas", alcunha que lhes fora dada até o momento, mas como "povo da mata", e a se autodesignar como Forças Guerrilheiras do Araguaia (FOGUERA). Chegaram, inclusive, a emitir documentos que buscavam apresentar à população os motivos que orientavam a sua luta. Além disso, com o apoio de um número (ainda que reduzido) de moradores da região, criaram a União Pela Liberdade e pelos Direitos do Povo (ULDP), chegando a fazer circular um programa com vinte e sete pontos que continham o programa político que norteava a sua atuação.

A repressão à FOGUERA esteve diretamente relacionada a algumas das medidas autoritárias tomadas pelo Estado brasileiro, durante os governos militares e especialmente reforçadas durante o Governo Médici (1969-1974) - como a colocação em prática do que preconizava o AI-5 e a Doutrina de Segurança Nacional, lançando-se mão de todos os dispositivos possíveis contra sujeitos e grupos taxados naquele contexto autoritário como subversivos e terroristas, vistos como inimigos internos. Napolitano compara as medidas desproporcionais adotadas nos "anos de chumbo", naquele momento, com um martelo de matar moscas. Segundo ele:

O martelo de pilão da repressão não matou apenas moscas, mas tudo o que ousasse voar. O regime militar montou uma grande máquina repressiva que recaiu sobre a sociedade, baseada em um tripé: vigilância - censura - repressão. No final dos anos 1960, este tripé se integrou de maneira mais eficaz, ancorado em uma ampla legislação repressiva que incluía a Lei de Segurança Nacional, as leis de censura, os Atos Institucionais e Complementares, a própria Constituição de 1967. Não foi o regime de 1964 que inventou esse tripé repressivo, em parte herdado do passado, mas sem dúvida deu-lhe nova estrutura, novas agências e funções. ${ }^{14}$

Como lembra Coimbra, entre 1967 e 1972 foram criados diversos aparelhos repressivos, como o Centro de Informações do Exército (CIE), em 1967; e o Centro de Informações da Aeronáutica (Cisa), em 1970. Já o Centro de Informações da Marinha, Cenimar, existente antes do início da Ditadura, fora reorganizado em 1971. É importante lembrar que esses órgãos ajudavam a tornar mais eficientes as ações do Serviço Nacional de Informação (SNI), criado em 1964. Ainda segundo a mesma autora:

O regime passou a se preocupar com uma maior integração entre os organismos repressivos já existentes. Esta deveria ser efetivada sob a hegemonia do Exército, não somente por ser a Arma de maior contingente, mas também porque a Doutrina de Segurança Nacional conferia-lhe papel especial na nova concepção de guerra, contra um "inimigo interno", e envolvendo especialmente forças terrestres. ${ }^{15}$

A região amazônica brasileira é historicamente caracterizada pelos conflitos decorrentes da luta pela terra, envolvendo indígenas, quilombolas, posseiros, seringueiros e outros sujeitos. Tais lutas se aceleraram durante a Ditadura, período em que ocorreram inúmeras atrocidades em todo o Norte do Brasil, mas, sobretudo na zona de fronteira das chamadas frentes de expansão. ${ }^{16}$

Em 1966, chegaram à região os primeiros militantes do $\mathrm{PCdoB}$, norteados por uma concepção político-ideológica sistematizada a partir da experiência revolucionária chinesa, que se popularizou pela denominação "maoísmo" e caracterizou-se pela concepção de "guerra popular prolongada" (visando o cerco da cidade a partir do campo), bem como pela defesa da guerra de Guerrilha, a qual concebe o campesinato como base social e política fundamental no processo revolucionário $e$ o Partido como dirigente desse processo.

\footnotetext{
${ }^{14}$ NAPOLITANO, Marcos. 1964: História do Regime Militar Brasileiro. São Paulo: Contexto, 2018.

${ }^{15}$ COIMBRA, Doutrinas..., p. 12.

${ }^{16}$ VELHO, Otávio Guilherme. Frentes de Expansão e estrutura agrária: estudo do processo de penetração numa área de Transamazônica. 3. ed. Manaus: UEA Edições, 2013.
} 
O PCdoB identificou a região do Araguaia como sendo propícia à deflagração da luta armada sob a forma de guerrilha, sobretudo para aqueles que nutriam a convicção de que a luta armada deveria iniciar-se no campo e obter a ampla participação das "massas". Foram analisadas as características do sudeste do Pará e norte do então Goiás, bem como as condições de vida da população que ali residia.

Entre os municípios da região, destacava-se Marabá que, na época, passava por um período de crescimento, dado o papel que lhe estava sendo atribuído pelos governos militares no âmbito da implementação de projetos desenvolvimentistas e voltados para a integração nacional. Não à toa, assim como ocorrera em Xambioá, Marabá acabaria sendo escolhida pelos militares como um dos pontos logístico para a mobilização das tropas e como sede dos serviços de inteligência que seriam fundamentais para a vitória sobre a Guerrilha.

No início dos anos 1970, Marabá possuía, oficialmente, mais de 24 mil habitantes, sendo que mais de 14 mil estavam situados na área urbana concentrada no núcleo pioneiro, hoje conhecida como Velha Marabá, e praticamente 10 mil na zona rural. Esse número crescia a cada ano devido à grande quantidade de migrantes, sobretudo vindos do Maranhão, ${ }^{17}$ que passavam a residir no município. Um dos locais que foi alvo direto da expansão de Marabá naquele momento foi o espaço que hoje se constitui como o núcleo Cidade Nova, em cuja entrada foi instalado o DNER. Como mostra Almeida:

(...) uma outra parte da cidade encontrava-se em fase acelerada de expansão $e$ parecia ser a continuidade natural de Marabá: o bairro Amapá e entorno. Em 1971, a Transamazônica alcançou esse bairro, tornando-se um ponto de parada do fluxo migratório vindo do Nordeste. A facilidade de ocupação dos lotes mais baratos oferecidos pela Prefeitura ajudou no crescimento da ocupação nas áreas próximas a esse núcleo (...) Alguns órgãos federais como o INCRA e o DNER instalaram-se lá. Nesse mesmo bairro havia o aeroporto que já ocupava uma área considerável e que depois foi ampliado. Em 1974, a área do bairro Amapá contava com 1.610 casas e 4.456 pessoas. ${ }^{18}$

Segundo depoimento dado à CNV pelo senhor Manoel Messias Guido Ribeiro, que viria a ter contato com o espaço do DNER enquanto morador da região e posteriormente recruta do Exército no período final da Guerrilha: "Marabá na época era muito pequena, não existia cidade nova, não existia Nova Marabá. Existia o INCRA e existia aqui, o Amapá chamava Glópula (Sic.), aqui no INCRA, parte do Amapá, e Marabá era bem pequeno. Cheguei em Marabá na década de 70" ${ }^{19}$

Pós 1972, ano em que a presença dos militantes do PCdoB fora descoberta, a cidade passaria a ver, também, a ampliação da presença de militares. Como descreve Campos Filho, no período inicial da Guerrilha, "Marabá e Xambioá tiveram suas rotinas radicalmente modificadas devido à presença numerosa dos soldados. A população não entendeu o que estava acontecendo, não via motivo aparente para aquela movimentação". ${ }^{20}$

Essa presença dera seus passos iniciais em 1970, quando Marabá fora decretada como área de Segurança Nacional, passando a colaborar com a Doutrina de Segurança Nacional instituídas pelos militares. Nesse ano, e em 1971, duas grandes operações militares foram realizadas na região do Bico do Papagaio, onde seriam posteriormente desenvolvidas as ações guerrilheiras. Respectivamente, foram efetuadas as operações Carajás e Mesopotâmia, objetivando localizar militantes de movimentos políticos contrários à Ditadura, que estariam instalados na região, com o objetivo de promover ações de guerrilha rural.

Segundo o relatório da CNV, "os agentes seguiram pistas que poderiam levar a militantes do PRT,

\footnotetext{
${ }^{17}$ Ver: SILVA, Idelma Santiago. Migração e cultura no Sudeste do Pará: Marabá (1968-1988).2006. 181f. Dissertação (Mestrado em História) — Universidade Federal de Goiás, Goiânia, 2011; e SILVA, Idelma Santiago da. Fronteira Cultural: a alteridade maranhense no sudeste do Pará (1970-2008). 2011. 230 f. Tese (Doutorado em História) — Universidade Federal de Goiás, Goiânia, 2011.

${ }^{18}$ ALMEIDA, José Jonas. A cidade de Marabá sob o impacto dos projetos governamentais. 2008. 272 f. Dissertação (Mestrado em História Econômica) - Universidade de São Paulo, São Paulo, 2008, p. 76.

19 Depoimento de Manoel Messias Guido Ribeiro, ACERVO CNV, 2014. Disponível em: http://cnv.memoriasreveladas.gov.br/todos-volume-1/658-documentos-sobre-a-guerrilha-do-araguaia.html. Acesso: 15. Dez. 2016.

${ }^{20}$ CAMPOS FILHO, Guerrilha do Araguaia..., p. 140.
} 
da AP, da ALN, da VAR-Palmares e da Ala Vermelha naquela região". ${ }^{21}$ Para tanto, em paralelo aos serviços de inteligência, foram realizadas exibições militares com a utilização de bombas $e$ a apresentação de pára-quedistas na praia do Tucunaré, em Marabá.

Depois de 1972, o combate à guerrilha foi desenvolvido por intermédio de três momentos. Durante a Primeira Campanha, iniciada pelas Forças Armadas sob o comando dos Generais Antônio Bandeira e Viana Moog, os militantes do PCdoB, que ainda se encontravam em fase de preparação militar, foram surpreendidos.

É importante observar que, entre 1966, ano da chegada dos primeiros militantes, e 1972, em que os projetos guerrilheiros foram descobertos, os membros do $\mathrm{PCdoB}$ da região não haviam apresentado à população os seus propósitos de ação no Araguaia. No entanto, já praticavam exercício de aproximação junto a essa população, buscando compreender melhor sua realidade e suas condições de vida na lida no campo e na convivência com a floresta.

Conseguiram a simpatia da população e após serem descobertos, no início de 1972, abandonam os locais que ocupavam até então e migram para o interior das matas, passando a ser designados pelos moradores como "povo da mata". Colocam em prática a sua organização em três destacamentos, "A", "B" e "C", constituídos cada um por cerca de 20 guerrilheiros, subordinados ao comando do destacamento que, por sua vez, estava subordinado a uma Comissão Militar. O destacamento "A" atuava nas proximidades de São Domingos e São João do Araguaia; o destacamento "B" atuava no entorno de Palestina, Brejo Grande, São Geraldo e outros espaços próximos ao nordeste da atualmente designada Serra das Andorinhas; o destacamento "C", por sua vez, atuava próximo à região sudoeste da mesma serra. Cada um deles possuía bases específicas. Além disso, o translado dos guerrilheiros, antes ou depois de iniciada a Guerrilha, não se dava apenas nos locais delimitados a cada destacamento, sendo realizado o trânsito entre boa parte do Sul e Sudeste do Pará e no local em que, à época, era o norte de Goiás.

No dia 12 de abril de 1972, o Exército atacou o Destacamento "C" (Base dos Caianos) e no dia 14 atacou o Destacamento "A" (Base da Faveira). Foi realizada grande movimentação de tropas pela região, vindas, sobretudo, de outras localidades, como Belém e Manaus. A CNV estima que cerca de dois mil soldados tenham sido mobilizados nessa fase. A Velha Marabá passou a contar com a intensa movimentação de soldados, alterando o seu cotidiano.

Seria, no entanto, a partir da segunda campanha que a ocupação militar da região ganharia um maior contorno. Segundo Campos Filho, nessa campanha:

Foram utilizados, principalmente, recrutas do Batalhão de Selva, regimento instalado à altura do quilômetro oito da rodovia Transamazônica; pretendia-se garantir a presença de elementos da própria região. Embora esses soldados recebessem treinamento de luta anti-guerrilheira, isso era feito de forma precária - como em geral se dão os treinamentos de recrutas. ${ }^{22}$

A segunda campanha foi designada como Operação Papagaio, que se consistiu na movimentação de tropas aliadas a Ação Cívico-Social (Aciso). A campanha, comandada pelos generais Antônio Bandeira, Vianna Moog e Hugo Abreu, iniciou-se em setembro de 1972, quando o Exército retornou à região com aproximadamente 2 mil militares, com apoio da Aeronáutica e da Marinha, incluindo tropas profissionais. Nessa campanha, assim como na primeira, as Forças Armadas atuaram regularmente fardadas. Porém, adotaram novas táticas, visando a derrotar o mais rápido possível a Guerrilha: procuraram conquistar a simpatia da população com o início da Operação Aciso e manter os "guerrilheiros" ainda mais isolados; recrutaram mais guias, construíram mais bases militares $e$ usaram a propaganda e a guerra psicológica.

Quanto à Marabá, Campos Filho destaca:

Enquanto os secretas coletavam informações, dadas de bom grado por lavradores (que têm como características a simplicidade de receber bem a todos), uma estrutura ia sendo preparada para dar sustentação à terceira campanha, que estava sendo meticulosamente planejada. Constituíram-se alguns quartéis nas principais cidades,

\footnotetext{
${ }^{21}$ BRASIL, Comissão Nacional da Verdade, Relatório: Volume I, 2014, p. 614.

${ }^{22}$ CAMPOS FILHO, Guerrilha do Araguaia..., p. 151.
} 
Imperatriz e Marabá, e instalaram-se na região, no quilômetro oito da rodovia Transamazônica, o $52^{\circ}$ Batalhão de Infantaria da Selva e a $23^{a}$ Brigada de Infantaria de Selva. ${ }^{23}$

Entre outubro de 1972 e 1973, após terem sido malsucedidos no desmonte da Guerrilha durante as duas primeiras campanhas, os militares realizaram um recuo estratégico e mudaram a forma de operacionalização de suas ações, passando a investir na infiltração de agentes no interior da população local e em outras estratégias não mais voltadas para a mobilização massiva de tropas, mas que fundamentavam sua ação em medidas mais efetivas de inteligência e de arregimentação de membros da população da região, como a intimidação, a tortura e a oferta de lotes próximos às estradas operacionais (OPs) recém construídas, o que muitas vezes acabava envolvendo os mesmos indivíduos.

Nesse período, algumas táticas foram usadas pelo Exército para isolar os guerrilheiros, dentre elas o cerco total da área para retirar os moradores dos lotes que podiam ser de acesso aos "terroristas" $e$ transferi-los para os lotes que ficavam às margens da rodovia Transamazônica e das OPs, e a destruição das lavouras dos camponeses (e dos indígenas Suruí-Aikewara, que tiveram seu território ocupado) que pudessem abastecer a Guerrilha.

A terceira fase consistiu no período de ações mais cruéis vivenciado pela maior parte dos indivíduos envolvidos direta ou indiretamente na luta armada, conforme descreve Corrêa:

A 7 de outubro de 1973, 750 membros das tropas especiais do Exército, escalonados em três grupo de 250 homens, operando em rodízio, entraram na selva em trajes civis com a única missão de extirpar os guerrilheiros, com máximo rigor e precisão cirúrgica. Saíram de lá em fins de setembro de 1974, com a guerrilha completamente dizimada. Foi nesse período de um ano que teriam ocorrido violações sistemáticas dos Direitos Humanos e das Convenções de Genebra, com tortura, decapitações e execução de prisioneiros. ${ }^{24}$

Essa campanha teve como resultado o aniquilamento da resistência guerrilheira. Nesse momento, ganha destaque as operações realizadas no âmbito da Casa Azul, como aponta Campos Filho:

A estratégia adotada e a preocupação com o sigilo que envolvia a operação demonstram que, desde a sua preparação, o objetivo dessa terceira ofensiva era aniquilar a resistência guerrilheira e não deixar nenhum vestígio do que ali acontecera. O quartel-general da operação funcionou no DNER, em Marabá, evitando um aparato militar que chamasse a atenção. Em Xambioá, funcionava o centro de operações mais importante. ${ }^{25}$

Ainda segundo o mesmo autor:

Da mesma forma que nas vezes anteriores, os prisioneiros eram encaminhados para Marabá, Bacaba, Xambioá, Araguaína, e até mesmo Brasília. Os locais de tortura, pelo que se pôde constatar, eram as prisões no DNER e no Incra, em Marabá, na Bacaba e em Xambioá - nesta última cidade um dos locais em que as pessoas ficavam presas era um imenso buraco, cavado na base militar, com uma enorme grade jogada por cima (apelidado de Vietnã), onde se acotovelavam dezenas de prisioneiros. Nus, ou apenas de calção, os presos enfrentavam um sol escaldante, como é típico da região, além de chuvas constantes que são comuns naquela época do ano. Água para beber era jogada raramente, e alimentação, poucas vezes servida. As necessidades fisiológicas eram feitas ali mesmo, causando um cheiro insuportável. Também em Marabá as condições das celas não eram diferentes: os presos passavam por essas mesmas humilhações, completamente privados de direitos, tratados como animais $e$ torturados por negarem fatos que desconheciam. ${ }^{26}$

\footnotetext{
${ }^{23}$ CAMPOS FILHO, Guerrilha do Araguaia..., p. 171.

${ }^{24}$ CORRÊA, Em algum lugar..., p. 42.

${ }^{25}$ CAMPOS FILHO, Guerrilha do Araguaia..., p. 172.

${ }^{26}$ CAMPOS FILHO, Guerrilha do Araguaia..., p. 142-143.
} 
Findos os combates, o ano de 1975 é caracterizado como o início da fase da Operação Limpeza, visando à eliminação de todo e qualquer vestígio material relativo às violações ocorridas durante a Guerrilha, incluindo-se o desaparecimento dos restos mortais dos guerrilheiros. As operações militares foram consideradas oficialmente encerradas em março daquele ano, mas ainda existiam marcas que poderiam, no futuro, gerar problemas para os agentes que ali atuaram, como corpos enterrados em locais clandestinos, restos mortais de pessoas que foram decapitadas após a morte e, como já dito, sinais diversos de uma sistemática violação aos direitos humanos.

Além disso, a partir do contexto da Guerrilha, Marabá e toda a área de sua atuação sofreram um processo de militarização, que exerceu influência nos conflitos sociais pela posse e permanência na terra e na manutenção da população sob vigilância e controle. Tentava-se, assim, não apenas evitar possíveis reorganizações de núcleos guerrilheiros, mas também impedir que moradores tornassem públicas suas memórias dos fatos ocorridos durante a Guerrilha.

\section{A Operação Limpeza e a busca pelas "memórias difíceis"}

Finalizados os combates da Guerrilha, iniciou-se, no cerne da sociedade brasileira, uma nova batalha em relação ao conflito, que não mais envolvia revólveres, rifles, metralhadoras ou qualquer forma de armamento bélico, mas que colocava em disputa as narrativas acerca daquele episódio e, diretamente relacionadas a elas, informações acerca do paradeiro de muitas das pessoas que ali tombaram, assim como em relação às circunstâncias de aprisionamento e morte de guerrilheiros $e$ camponeses.

No ano de 1975, muitos dos relatos do pós-guerrilha convergem para a realização - por parte de agentes militares que atuaram no conflito, com o apoio de civis que teriam atuado como mateiros da chamada Operação Limpeza, que guardaria o segredo do porquê até hoje é escasso o número de restos mortais localizados de guerrilheiros, limitando-se a dois: Maria Lúcia Petit (Maria) e Bergson Gurjão Farias (Jorge). Também foram localizados restos mortais atribuídos ao guerrilheiro Francisco Manoel Chaves (Preto Chaves), mas não foram identificados parentes para que se realizasse a confirmação pelo DNA.

Muitos anos após a Operação Limpeza, mesmo em publicações de autoria de militares, apareceram relatos sobre o apagamento de rastros envolvendo os restos mortais dos guerrilheiros. $\mathrm{O}$ Tenente reformado Jiménez, da Aeronáutica, por exemplo, ao tratar da base de operações da Bacaba, afirma que:

Num terreno bem próximo deste campo de futebol foram enterrados alguns guerrilheiros que, no término da operação em 1975, foram exumados, colocados em sacos plásticos e levados em helicópteros da FAB para a Serra das Andorinhas, onde foram cremados. $^{27}$

É importante lembrar que, em 1975, os militares de todo o mundo, principalmente após a experiência dos julgamentos da alta cúpula nazista no tribunal de Nuremberg (1945-1946), já conheciam o destino que poderia ser dado a posteriori a casos em que as condutas de guerra fossem marcadas por ações que desrespeitassem as regras até então aceitas para os conflitos bélicos, a exemplo das já citadas convenções de Genebra. Mesmo no mundo socialista, havia há pouco sido revelado por Nikita Kruschev as atrocidades cometidas sob o comando do governo de Josef Stálin no cerne da União Soviética, fator que provocou o rompimento com a linha soviética e dissidências em boa parte dos movimentos e partidos ligados ao comunismo em todo o mundo.

No Araguaia, além da morte e do desaparecimento dos guerrilheiros, foi promovido um apagamento dos rastros deixados em relação à boa parte dos atos praticados pelos militares, assim como mantido um silenciamento oficial a respeito da própria existência da Guerrilha. A depender dessas ações, hoje a Guerrilha do Araguaia seria um acontecimento desconhecido pela sociedade brasileira. Segundo Corrêa: "Com a chamada Operação Limpeza, desencadeada a partir de 1975, boa parte dos acervos dos órgãos de inteligência militar, SNI, CIE, CISA e Cenimar, acabou destruída". ${ }^{28}$

\footnotetext{
${ }^{27}$ JIMÉNEZ, José Vargas. Bacaba: memórias de um guerrilheiro de Selva da Guerrilha do Araguaia. Campo Grande: Edição do autor, 2007, p. 43.

${ }^{28}$ CORREAA, Em algum lugar..., p. 555.
} 
No mesmo sentido, Morais e Silva destacam que:

Os brasileiros pouco souberam sobre a guerrilha nos anos seguintes à luta no Araguaia. O governo impôs a lei do silêncio e a imprensa quase nada publicou sobre o assunto. Apenas alguns familiares conheciam o destino dos militantes do PCdoB enviados ao sudeste do Pará, pelos relatos dos prisioneiros sobreviventes, apanhados no início dos combates. ${ }^{29}$

De acordo com o já citado Manoel Messias Guido Ribeiro, recruta do Exército à época da Guerrilha, a operação limpeza foi realizada com o objetivo de apagar rastros do que havia ocorrido na região do Araguaia:

Teve sim, a operação limpeza, teve duas operações limpeza longas. Houve a operação limpeza? Sim. É inegável, não adianta dizer para o senhor, porque é inegável, quem tem conhecimento da região sabe, houve a operação limpeza. Inclusive esse saco de ossos era na operação limpeza. O que é a operação limpeza? Vocês já sabem não é, retirar tudo que venha a deixar rastros ou coisas desse gênero. ${ }^{30}$

Como se sabe, à revelia desse processo de apagamento e silenciamento, foi-se ampliando, com o passar dos anos, as reivindicações por parte dos familiares dos mortos e desaparecidos sobre o paradeiro de seus filhos, irmãos, sobrinhos e netos, assim como ocorreu com familiares e sujeitos vitimados em outros episódios relacionados à Ditadura Militar. Assim, fora criada em 1995 a Comissão Especial de Mortos e Desaparecidos Políticos (CEMDP), hoje vinculada à Secretaria de Direitos Humanos da Presidência da República.

Esses familiares buscavam informações sobre o paradeiro ou, cada vez mais, o detalhamento sobre as formas de morte e os locais de sepultamento dos restos mortais dos combatentes, assim como a garantia de que as mortes fossem oficialmente atestadas. Tais solicitações foram, durante muito tempo, ignoradas por parte do Estado brasileiro. Além disso, as Forças Armadas, mesmo com a abertura democrática e o fim da Ditadura, deram continuidade à opção de não apresentar os dados solicitados pelos familiares, sob a alegação de que os arquivos que poderiam apresentar esclarecimentos sobre os casos tinham, em geral, sido destruídos à época dos conflitos.

Enquanto isso, na região onde ocorreu a Guerrilha, as populações camponesas continuavam reproduzindo as memórias do conflito de forma subterrânea ${ }^{31}$ através do diálogo entre familiares, compadres e outras formas que não ganhassem maior difusão ou pudessem contrariar interesses de agentes da repressão que continuavam a viver $e$ a ter forte poder a nível local.

Era amplo o temor ou outras formas de interdição que alimentavam o silenciamento sobre a Guerrilha, o que era justificado, em alguns casos, pela contribuição de muitos moradores com as ações do aparato repressivo, e, por outros, pelo fato de terem sido alvos desse mesmo aparato, dada a suspeita - recaída sobre muitos - de terem colaborado com os guerrilheiros e saber, no calor dos conflitos, do seu paradeiro e dos planos que tinham como objetivo executar. ${ }^{32}$

Esses camponeses acabariam envolvidos, mesmo sem saber, com as ações de reconhecimento de terreno, adaptação e ação política dos militantes do PCdoB, assim como, já durante os combates, com as estratégias de obtenção de informação por parte dos militares. $\mathrm{E}$, como dito anteriormente, nos anos imediatos aos combates, adotariam para si a estratégia de silenciamento "sugerida" pela ação dos militares, que ainda continuavam com grande influência na região. ${ }^{33}$

Os contatos entre esses dois grupos envolvidos com o conflito - familiares de militantes

\footnotetext{
${ }^{29}$ MORAIS; SILVA, Operação Araguaia..., p. 537.

30 Depoimento de Manoel Messias Guido Ribeiro, ACERVO CNV, 2014. Disponível em: http://cnv.memoriasreveladas.gov.br/todos-volume-1/658-documentos-sobre-a-guerrilha-do-araguaia.html. Acesso: 15 . Dez. 2016.

${ }^{31}$ POLLAK, Michael. Memória, esquecimento, silêncio. Estudos históricos, Rio de Janeiro, v. 2, n. 3, 1989, p. 3-15.

${ }^{32}$ SILVA, Wellington Sampaio da. A Guerra Silenciada: memória histórica dos moradores do Bico do Papagaio sobre a Guerrilha do Araguaia. 2008. 146 f., Il. Dissertação (Mestrado em História) — Universidade Federal da Paraíba, João Pessoa, 2008; REIS, Naurinete Fernandes Inácio. Memória social e Guerrilha do Araguaia. 2013. 172 f. (Dissertação Mestrado em Sociologia) — Universidade Federal de Goiás, Goiânia, 2013; MECHI, Os protagonistas do Araguaia...

${ }^{33}$ Sobre a continuidade dessa influência, ver em especial o já citado: NOSSA, "Mata! O Major Curió...
} 
desaparecidos e camponeses da região do Araguaia - começaram a se intensificar à medida que grupos de familiares passaram a se deslocar até o Pará e o Tocantins em busca de informações que pudessem clarear a compreensão sobre a atuação de seus entes queridos na Guerrilha, bem como que pudessem solucionar o mistério em torno dos seus paradeiros. Nesse sentido, ganhou repercussão a Caravana dos Familiares dos Desaparecidos do Araguaia, realizada em 1980, que teve entre seus integrantes o advogado paraense Paulo Fonteles. Como destaca Peixoto: "A Caravana de 1980 mobilizou setores críticos da sociedade e reabriu a história da guerrilha, que os militares queriam encerrada nos seus arquivos secretos". ${ }^{34}$

A iniciativa dos familiares deu início, desse modo, a uma série de ações que principiaram nos próprios anos 1980 e transpassariam o ano de 2010, momento em que o Brasil fora condenado, internacionalmente, por meio do já citado Caso Gomes Lund e outros ("Guerrilha do Araguaia") vs. Brasil na Corte IDH, que ordenou ao Estado brasileiro a promover outras medidas de reparação.

Tal condenação resultou, entre outras medidas, na criação da CNV, que teve atuação entre 2012 e 2014. Ainda que se considere tímida a ação da CNV - vista como uma comissão de cunho conciliatório, ${ }^{35}$ em comparação com outras comissões semelhantes criadas em países como a Argentina e em outros lugares que se depararam com o problema de lidar com memórias difíceis legadas por regimes autoritários - , essa apresentou ao Brasil um relatório final em que são retomados temas voltados para a Guerrilha do Araguaia, dando visibilidade à Casa Azul.

Por intermédio da CNV, a Casa Azul, que já havia sido anteriormente figurada perifericamente em publicações e reportagens ligadas à Guerrilha ou temas locais, teve a sua história exumada frente à população marabaense e à sociedade brasileira como um todo, e perdeu, ao menos em parte, a camuflagem que estrategicamente ganhara desde o período em que servira de instalação ao CIE.

\section{O desvelamento de memórias sobre a Casa Azul}

Imagem 1 - Ex-soldado Guido e o camponês Pedro Mariveti compartilham memórias nas dependências da Casa Azul, atual DNIT (2014).

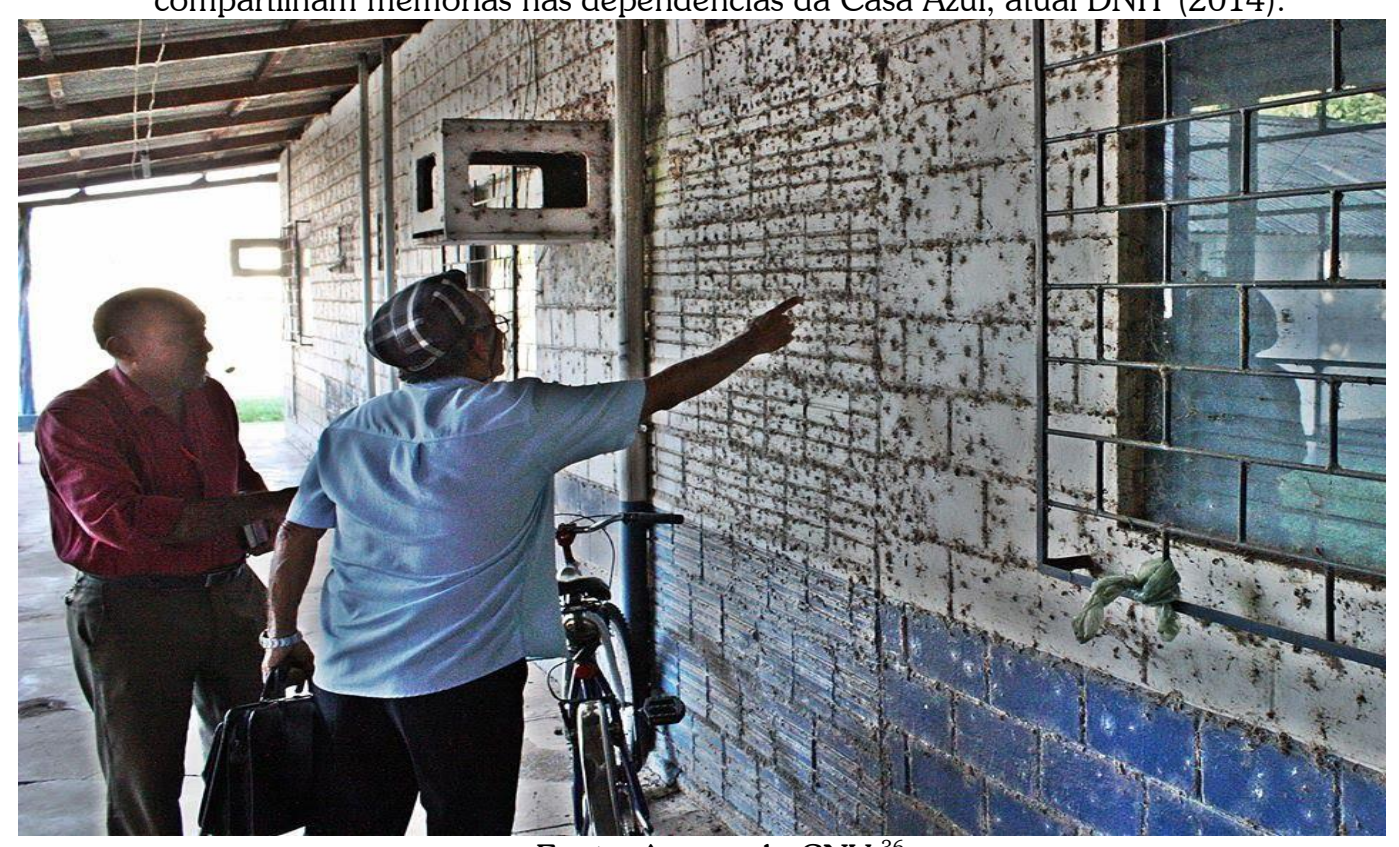

Fonte: Acervo da CNV. ${ }^{36}$

A imagem fora produzida durante diligência da CNV à Casa Azul, em Marabá, realizada no ano de 2014. Na ocasião, os senhores Manoel Messias Guido Ribeiro e Pedro do Nascimento, conhecido como Pedro Marivete, apresentaram depoimentos à comissão, relatando um pouco do que viveram $e$ presenciaram naquele espaço. Registra a permanência de ambos e de parte das instalações do espaço,

\footnotetext{
${ }^{34}$ PEIXOTO, Memória social da Guerrilha do Araguaia..., p. 485.

${ }^{35}$ MOTTA, História, memória e as disputas...

${ }^{36}$ Disponível em: http://cnv.memoriasreveladas.gov.br/images/jpg/fotos eventos/15 092014 foto6.jpg, Acesso: 10. Jan. 2018.
} 
passados 40 anos do fim da Guerrilha. Essas instalações, no que concerne ao prédio em "L" (utilizado como centro de tortura), encontram-se pouco preservadas, servindo hoje, 2018, como depósitos para materiais do DNIT.

O caminho (ainda em desenvolvimento) para que a divulgação do que ocorrera no âmbito da Casa Azul acontecesse fora marcado pela lenta aparição de novas informações e novos rastros. Informações como os depoimentos desses dois homens, que viram o local e a Guerrilha de lugares sociais distintos: o primeiro (Guido), como um morador da região que servira como cabo do Exército; o segundo (Marivete), como morador aprisionado, sob acusação de apoiar os guerrilheiros. Ambos, juntamente com os moradores locais Abel Honorato e Raimundo de Souza Cruz (Barbadinho), e o sargento João Santa Cruz Sacramento, deram depoimentos sobre a Casa Azul, que são citados para ilustrar um pouco do que acontecera naquele espaço de detenção e tortura. ${ }^{37}$

Além desses depoimentos, para compreensão da história da Casa Azul, também se faz importante que sejam recuperados relatos, ainda que escassos, apresentados por oficiais reformados do Exército $e$ da Aeronáutica, ainda que esses sujeitos muitas vezes produzam depoimentos dispersos e cheios de nuances que dificultam um entendimento mais aprofundado. Parte desses relatos está hoje publicada em livros, em que militares que se encontram na reserva narram a história da Guerrilha do seu ponto de vista.

Payne ${ }^{38}$ lança problematizações sobre testemunhos de perpetradores de violência em contextos autoritários, sobretudo aqueles veiculados por agentes de segurança pública (em destaque militares $e$ policiais) de estados que passaram por regimes autoritários no final do século XX, especialmente durante as ditaduras que afligiram a América Latina, e o regime do Apartheid, na África do Sul. Problematiza, ainda, compreensões veiculadas pela justiça de transição, com base no poder político de tais confissões, e pontua que: "Más que pedir disculpas por sus actos, los perpetradores tienden a racionalizarlos y a minimizar su responsabilidad personal, aumentando así la tensión sobre el pasado, en vez de disminuirla." 39

Em diversos momentos, Payne trata do testemunho de perpetradores brasileiros, destacando de forma muito pertinente os silêncios lançados por aqui a respeito dos desaparecimentos políticos e da falta de um maior esforço do Estado, sobretudo das Forças Armadas, para trazer à tona informações sobre os mortos e desaparecidos do período militar. Em um dos capítulos de sua obra, "Ficción y Mentiras", ela toma como objeto a novela "Xambioá: Guerrilha do Araguaia", de Pedro Corrêa Cabral, coronel da Força Aérea que servira no Araguaia.

Payne pontua bem o artifício utilizado por Cabral de usar o gênero literário para narrar fatos que, sem esse recurso, poderiam causar-lhe problemas junto àqueles que, assim como ele, combateram a Guerrilha, mas que não têm interesse em ter divulgadas as atrocidades que cometeram. Segundo Payne: "Algunas confesiones, apenas si basadas em hechos o como pura invención, se asemejan a una ficción disfrazada de verdad. Cabral empleó la técnica contraria: narrar los hechos como ficción" ${ }^{40}$

Cabral foi um dos primeiros, em 1993, a falar publicamente sobre a Operação Limpeza. Também foi dos primeiros a tratar sobre a Casa Azul. No trecho do seu romance, por exemplo, é feita a alusão a um momento do cotidiano da Casa Azul, relativo à morte de Osvaldão (Osvaldo Orlando da Costa), líder do Destacamento "B" da Guerrilha:

Na Casa Azul, após a reunião do pôr-do-sol, Oran, Gil, o Gordo, Zeca e outros escutavam a rádio Tirana. "Bravos guerrilheiros do Araguaia, vamos resistir com firmeza às forças imperialistas do governo corrupto e desumano do Brasil..." O assassinato covarde do herói Osvaldo Oliveira Couto (sic.) enche de indignação o povo brasileiro. Porém, a morte do valente e destemido tenente Osvaldão, do Exército Popular, exalta os ânimos e a vontade de vencer dos trabalhadores e camponeses. ${ }^{41}$

\footnotetext{
${ }^{37}$ BRASIL, Comissão Nacional da Verdade, "Relatório: Volume I", 2014. Ver capítulo 15.

${ }^{38}$ PAYNE, Leigh A. Testimonios perturbadores. Ni verdad ni reconciliación en las confesiones de violencia de Estado. Universidad de los Andes, 2009.

${ }^{39}$ PAYNE, Testimonios perturbadores..., p. 1.

${ }^{40}$ PAYNE, Testimonios perturbadores..., p. 209.

${ }^{41}$ CABRAL, Pedro Corrêa. Xambioá: Guerrilha no Araguaia. Rio de Janeiro: Record, 1993, p. 115.
} 
São diversas as menções à Casa Azul durante a obra, sendo feitas representações sobre o cotidiano no local durante as operações de combate aos guerrilheiros. Cabral chega a apresentar uma definição sobre a Casa Azul:

A Casa Azul era o quartel-general do comando anti-guerrilha e, agora, estava ocupada pelos agentes de inteligência do CIE - Centro de Informações do Exército - e do CISA - Centro de Informações e Segurança da Aeronáutica, desde a retirada das tropas da região, quatro meses atrás. Originalmente, o prédio fora construído para abrigar os escritórios do DNER, durante a abertura da Transamazônica. A residência estava plantada nos altos barrancos da margem direita do Itacaiúnas, com o fundo voltado para o rio e a frente, para um grande descampado. Na parte fronteira, uma espécie de campo cerrado, reinava majestosa uma árvore enorme, como mais de trinta metros de altura e, seguramente, mais de um século de existência (...). A Casa Azul ganhara tal denominação por ter sua cobertura de telhas de amianto pintadas na cor azul-anil, mas suas paredes externas eram de madeira, caiadas de branco, o tom dominante. (...) Ao lado do prédio principal, havia um galpão que fora adaptado para abrigar os agentes e servidores menos graduados, bem como uma sala de interrogatório $e$ algumas celas cujas portas eram gradeadas de ferro. ${ }^{42}$

É importante observar que a obra de Cabral ou os depoimentos que serão discutidos adiante não se configuram como a versão oficial produzida pelas Forças Armadas, que silencia a respeito da Casa Azul. Todavia, apresentam enquadramentos coletivos das memórias que circulavam entre parte dos que atuaram no contexto da Guerrilha, sem eliminar visões conflitantes entre os próprios agentes das Forças Armadas sobre os episódios narrados.

Outro desses agentes a tratar da Casa Azul é José Vargas Jiménez, que entrou para a reversa em 1994 como Segundo-Tenente do quadro de Auxiliar de Oficiais do Exército Brasileiro. O tenente afirma que seu codinome durante a Guerrilha era "Chico Dólar". Jiménez é autor de duas obras sobre a Guerrilha: Bacaba: memória de um guerrilheiro de selva da Guerrilha do Araguaia (2007) e Bacaba II: toda a verdade sobre a Guerrilha do Araguaia e a Revolução de 1964 (2011). Em sua primeira obra sobre o tema, são relatadas algumas movimentações realizadas na Casa Azul:

Lá chegando, fomos para a 'Casa Azul', sede do Instituto Nacional de Colonização e Reforma Agrária (INCRA), localizada no Bairro do Amapá da cidade de Marabá-PA, logo após o Rio Itacaiúnas (sic.), onde ficava a base de comando de combate, as (sic.) Forças Guerrilheiras do Araguaia (FOGUERA) ${ }^{43}$ (...) Na madruga do dia 3 de outubro de 1973, o meu GC, o do Sgt Elizeu e do Sargento. Brito, comandados por Curió e guiados por Ivan, saímos da 'Casa Azul', com as missões de captura, destruição, busca $e$ apreensão, em camionetas pretas do INCRA, que nos conduziram pela rodovia Transamazônica, até um certo ponto já pré-determinado na orla da selva e dali seguimos a pé até o povoado de Bom Jesus, onde, após cercá-lo, entramos de casa em casa, fazendo prisioneiros, os camponeses que apoiavam os guerrilheiros, que totalizaram aproximadamente trinta, todos suspeitos de dar cobertura e apoiar os guerrilheiros. ${ }^{44}$

Mais adiante, na mesma obra, pontua que:

Existia também um campo de futebol do outro lado da rodovia Transamazônica, em frente aos barracões, onde os GC que ficavam na base praticavam esporte para se manter em forma e também era usado para pouso de helicópteros que faziam o transporte dos GC para a selva, seu resgate e de prisioneiros para a 'Casa Azul' ${ }^{45}$

\footnotetext{
${ }^{42}$ CABRAL, Xambioá..., p. 25.

43 JIMÉNEZ, José Vargas. Bacaba: memórias de um guerrilheiro de Selva da Guerrilha do Araguaia. Campo Grande, Edição do autor, 2007, p. 41. O autor, apelidado de Chico Dólar, suicidou-se em 2017 em Campo Grande-MS. Era um dos suspeitos do assassinato do guerrilheiro Demerval de Souza Pereira (João Araguaia), nas dependências da Casa Azul, conforme relato apresentado ao anexo AE do GTT. Disponível em: https:/apublica.org/wp-content/uploads/2012/01/Depoimento-deColaboradores-3.pdf, Acesso: mar. 2018.

44 JIMÉNEZ, Bacaba: memórias..., p. 41.

45 JIMÉNEZ, Bacaba: memórias..., p. 43.
} 
Nos relatos anteriores, além da identificação da existência de um espaço denominado Casa Azul (no bairro do Amapá e à beira do rio Itacaiúnas, em Marabá), são apresentadas as informações presentes também nos depoimentos orais, dados à $\mathrm{CNV}$, de outros militares que serviram no local, como a utilização da Casa Azul como espaço a partir da qual eram iniciadas algumas das operações, a utilização de veículos oficiais de órgãos como o Incra em missões envolvendo o combate a Guerrilha, o aprisionamento de camponeses acusados de dar apoio aos guerrilheiros e o resgate de prisioneiros para a Casa Azul.

Alguns anos antes da obra de Jiménez, foram apresentadas as referências ao local em que o Tenente-Coronel reformado Lício Maciel narra ao jornalista Luiz Maklouf Carvalho sua trajetória no Araguaia. Em 1973, após ter sido atingido no rosto pela guerrilheira Sônia (Lúcia Maria de Souza), em combate onde ela fora fuzilada, o Tenente-Coronel relata ter sido levado para atendimentos médicos na enfermaria da Casa Azul:

- Onde o senhor ficou em Marabá, exatamente?

- Na enfermaria do Comando de Operações de Marabá. Na 'Casa Azul'. Muito bonita, em cima de uma colina, à beira do rio Itacaiúnas. Muito grande. Cheia de Galpão. Era a sede de um órgão público, acho que o DNER. Tinha uma enfermaria. Eu instalei uma estação-rádio de um quilowatt, para falar com todo o Brasil, direto de Marabá. Pra onde o comandante quisesse falar, ele falava. ${ }^{46}$

Na mesma entrevista citada acima, Macie ${ }^{47}$ relata que a Casa Azul fora preterida no momento de planejamento das ações que objetivavam dar cabo das Forças Guerrilheiras, em 1973, durante a terceira campanha:

- Ele [Gal Milton Cerqueira] ficou em Marabá?

- Em Marabá, mas não na 'Casa Azul', que era muito cheia de interferência. O Cerqueira montou o acampamento dele na mata, e foi pra lá que fomos. O Cerqueira é que acabou com a guerrilha. Ele montou esse posto de comando lá e começou a agir como eu sempre agi. ${ }^{48}$

Anos depois, quando Maciel registra em livro de sua própria autoria sua versão a respeito da Guerrilha, faz alusão rapidamente à Casa Azul ao ironizar relatos que a apontam como local de morte do guerrilheiro Divino Ferreira de Souza, conhecido como Nunes, ferido em ação liderada por Maciel em outubro de 1973, quando morreram os guerrilheiros André Grabois (Zé Carlos), João Gualberto Calatroni (Zebão) e Antônio Alfredo de Lima. A respeito do tratamento dado a Nunes, enquanto prisioneiro ferido, Maciel aponta que:

O pessoal do PIC ficou com um helicóptero e voltamos no outro, levando o Nunes, para os primeiros socorros em Marabá. Devido à gravidade dos ferimentos, ninguém acreditava que ele se recuperasse. Dias depois, soube que ele morreu.

Dizem os comunas, que o mataram na Casa Azul. Quando Pedro Albuquerque tentou o suicídio na prisão em Fortaleza, se tivesse morrido, estariam dizendo a mesma coisa. Caso o Nunes não tivesse morrido, teria ficado aleijado, pois o projétil destruiu a articulação do braço com o ombro ${ }^{49}$.

Mas não fora apenas em obras de militares da reserva que se mencionou a Casa Azul. Muito antes dessas publicações relacionadas aos militares, precisamente em 1986, o espaço fora mencionado na

\footnotetext{
${ }^{46}$ CARVALHO, Luiz Maklouf. O coronel rompe o Silêncio: Lício Augusto Ribeiro, que matou e levou tiros na caçada aos guerrilheiros do Araguaia, conta sua história. Rio de Janeiro: Objetiva, 2004, p. 178, grifo nosso.

${ }^{47}$ A CNV aponta Maciel, codinome Dr. Asdrúbal, como um dos integrantes da equipe que atuava na Casa Azul, juntamente com: 1) Coronel Léo Frederico Cinelli; 2) Tenente-Coronel de Infantaria Wilson Brandi Romão, o "tio Zico", (primeira direção da Casa Azul); 3) Tenente-Coronel da Cavalaria Flávio Demarco, o "Tio Caco" (segunda direção da Casa Azul); 4) Tenente-Coronel Felipe Jorge; 5) Tenente-Coronel José Teixeira Brant; 6) Major Loureiro, codinome: Ricardo; 7) Major da Infantaria Sebastião Rodrigues de Moura, o Dr. Luchiri, Marco Antônio Luchiri ou Dr. Curió; 8) Major da artilharia Lício Augusto Ribeiro Maciel, o Dr. Asdrúbal”. In: BRASIL. COMISSÃO NACIONAL DA VERDADE. Relatório preliminar de pesquisa Centros clandestinos de violação de Direitos humanos: Volume I. Brasília: CNV, 2014.

${ }^{48}$ CARVALHO, O coronel..., p. 195-196, grifo nosso.

${ }^{49}$ MACIEL, Lício. Guerrilha do Araguaia: relato de um combatente. São Paulo: Schoba editora, s/d. p. 93, grifo nosso.
} 
obra do padre Ricardo Rezende Figueira, que atuava na Diocese de Conceição do Araguaia e na Comissão Pastoral da Terra (CPT).

A obra era intitulada "A justiça do Lobo" e tratava de um dos episódios da "guerra que veio depois" da Guerrilha, o conflito do Cajueiro, ocorrido em São Geraldo do Araguaia, onde 12 posseiros e dois padres franceses foram presos (em 1981) após os posseiros resistirem ao aparato policial constituído para expulsá-los de terras ocupadas há mais de 20 anos, mas que estavam sendo reivindicadas por três fazendeiros da região, com o apoio de órgãos como o Incra, o Grupo Executivo de Terras do Araguaia-Tocantins (Getat) e as polícias militar e federal. Durante a repressão aos posseiros, que organizaram resistência no cerne das matas, fora colocado em prática o mesmo modus operandi, sob o comando do Major Sebastião Rodrigues de Moura, o Curió (à época responsável pelo Garimpo da Serra Pelada), utilizado no combate aos guerrilheiros e, inclusive, sendo usados velhos mateiros na busca pelos posseiros entocados nas matas.

Em um trecho da obra, narra o padre Ricardo Rezende sobre relatos ouvidos junto a camponeses que atuaram na Guerrilha do Araguaia:

Por volta de trezentos homens foram levados para Bacaba, povoado no quilômetro 68 da Transamazônica, no Município de São João do Araguaia (era aí o quartel-general do Curió, base tática do Exército com um campo de aviação e lugar onde foram enterrados muitos guerrilheiros), e transferidos para a sede do DNER ao lado do rio Itacaiúnas, em Marabá. Outro local de prisão foi a antiga delegacia de Marabá. (...) [No local] Tinham gravado sons de gritos e os acionavam durante a tortura aumentando a tensão. Batiam e jogavam ao chão os lavradores. Fizeram um buraco ao lado da casa azul e os dependurava pelos pés. Colocaram nu e de quatro um rapaz sobre um formigueiro. Obrigavam-no a latir como cachorro. Quando achavam que não havia latido bastante alto ordenavam que se deitasse completamente sobre o formigueiro. ${ }^{50}$

Em 1995, dois anos após o lançamento do livro de Pedro Corrêa Cabral, o jornal Folha de São Paulo publicou a notícia "Câmara investiga ação do DNER em tortura", assinada por Abnor Gondim, em que é aludido relato de um desenhista (cuja identidade fora preservada) que teria atuado no âmbito do DNER e que teria dado depoimento à Comissão de Direitos Humanos da Câmara dos Deputados. A reportagem também cita o contato feito com Walter Moraes, telegrafista aposentado do DNER:

O desenhista afirmou à comissão que atualmente devem existir no local apenas alguns pedaços de ossos, porque durante esse tempo o rio Itacaiúnas (PA) encheu e inundou o local várias vezes. Outro funcionário do DNER na época, o telegrafista aposentado Walter Moraes, disse à Folha, por telefone, que durante dois anos era comum ver no local helicópteros do Exército aterrissando na área com prisioneiros encapuzados. Eles levavam os prisioneiros para um barracão, onde eles eram fotografados'. Alguns a gente viu voltando para os helicópteros. Outros, não, disse..$^{51}$

Em 2 de maio 1996, a Casa Azul ganhou visibilidade nacional ao ser alvo da reportagem do jornal o Globo intitulada "Ex-guia mostra onde os corpos foram enterrados", assinada por Amaury Ribeiro Junior, com a chamada "História secreta: ex-sede do DNER era usada como prisão, centro de tortura dos guerrilheiros e cemitério clandestino". O personagem central da reportagem é o ex-guia do exército, Manuel Leal Lima, o Vanu, que aparece numa foto junto as grades da casa utilizada como espaço de tortura:

Consciente de que suas revelações ajudarão a Comissão de Desaparecidos políticos a conseguir exumar os corpos, depois de mais de 20 anos, o ex-guia voltou à antiga sede do DNER para reconstituir cenas de terror da repressão à guerrilha. Sua memória foi reavivada logo que chegou à entrada do prédio, que até hoje se assemelha a uma cadeia.

\footnotetext{
${ }^{50}$ FIGUEIRA, Ricardo Rezende. A justiça do lobo: posseiros e padres do Araguaia. Petrópolis: Vozes, 1986, p. 29-30, grifo nosso.

${ }^{51}$ GONDIM, Abnor. Câmara investiga ação do DNER em tortura. Folha de São Paulo, São Paulo, 19. Ago. 1995. Disponível em: http://www1.folha.uol.com.br/fsp/1995/8/19/brasil/33.html, Acesso: 16. Mai. 2017.
} 
- É como se fosse hoje. Está tudo igual: as grades, a corrente e o quintal, que ainda tem sinais das covas - diz Vanu, mostrando uma das sete celas (três do lado esquerdo e quatro do lado direito) do lugar em que ele próprio ficou preso durante 18 dias. ${ }^{52}$

Alguns dias depois, precisamente a 6 de julho de 1996, O Globo publicaria reportagem em que o depoimento de Vanu e a Casa Azul seriam aludidos, sob o título "Militar que participou da repressão às atividades dos militantes do PCdoB rompe o silêncio". Como pontua Campos Filho, a série de reportagens do Globo realizadas em 1996 ajudaram a reavivar o debate sobre a Guerrilha, tendo grande destaque o depoimento de Vanu:

Mas foram as reportagens publicadas pelo jornal O Globo, em maio e junho de 1996, que reascenderam o interesse pela Guerrilha do Araguaia e levaram o assunto aos principais telejornais brasileiros, com um dossiê que estava em mãos de um militar, responsável por fotografar e arquivar informações sobre os guerrilheiros, os jornalistas divulgaram dados e fotos importantes e realizaram uma série de entrevistas com familiares dos desaparecidos, militares, ex-guerrilheiros, dirigentes do PCdoB e moradores da região, revelando novos dados a partir de depoimentos de ex-guias. Alguns inéditos, como o de Manuel Leal (Vanu), que apontou o DNER de Marabá como o local em que alguns guerrilheiros teriam sido enterrados, fazendo referência direta a Nunes (Divino Ferreira de Souza) e João Araguaia (Demerval da Silva Pereira) ${ }^{53}$

Por meio das publicações de jornais vinculados a chamada grande mídia e aos grandes grupos de comunicação, como a Folha, o Globo e o Estadão, a Guerrilha começava a ser inserida dentro de uma memória hegemônica ${ }^{54}$ que estava sendo construída sobre o regime militar, de cunho liberal, pretensamente mais democrática do que a dos grupos de esquerda que optaram pela luta armada, a qual buscava se afastar; bem como distante das concepções defendidas pelos militares; memória esta com a qual a memória sobre a Guerrilha passaria a ter uma relação de aproximação e distanciamento, sem perder suas marcas de alteridade.

Em 2009, o GTT vez vistoria na Casa Azul, coberta pelo jornal O Estado de São Paulo, em reportagem assinada por Leonencio Nossa, intitulada "Busca de ossadas no Araguaia começa hoje", que após tratar das possíveis mortes de guerrilheiro no local, registrou que:

A visita da expedição do Ministério da Defesa, no entanto, tem características simbólicas. É provável, segundo militares que participaram dos combates, que os corpos enterrados em bases como a da Casa Azul, de Xambioá e da Bacaba tenham sigo exumados durante a chamada Operação Limpeza, em 1975, e levados para cemitérios clandestinos da região. ${ }^{55}$

Na mesma reportagem, que também relata a morte do guerrilheiro José Piauy Dourado, o Ivo durante sessão de tortura na Casa Azul, é feito um relato sobre como teria ocorrido a morte e sepultamento do guerrilheiro Divino Ferreira de Souza, o Nunes, citado acima no relato do tenentecoronel Lício Maciel:

Já Divino Ferreira de Souza, o Nunes, ferido num combate, acabou morto numa sala do campo de extermínio. Soldados contaram mais tarde que o guerrilheiro foi sepultado numa cova rasa embaixo de um centenário pé de sumaúma, espécie típica

\footnotetext{
${ }^{52}$ RIBEIRO JR, Amaury. Ex-guia mostra onde os corpos foram enterrados. O Globo, Rio de Janeiro, 2 mai. 1996. Caderno O país, p. 8.

${ }^{53}$ CAMPOS FILHO, Guerrilha do Araguaia..., p. 253-254. Na já citada obra de Carvalho, é reproduzido o trecho em que o mesmo Vanu narrara para Campos Filho suas memórias sobre a presença de Nunes na Casa Azul: "Acorrentaram ele, e ficou no quarto. Eu passava pra lá, pra cá e via eles lá. Num chegava a conversar com eles... Ali era só do exército, ninguém podia conversar lá não. - Então o senhor não sabe se ele foi torturado nesse período. Vanu - Num sei não. - Provavelmente eles estavam dando anestesia pra ele dar informação. Vanu: - É, tava, pra dar informação". In: CARVALHO, O coronel rompe..., p. 154.

${ }^{54}$ NAPOLITANO, Marcos. Recordar é vencer: dinâmicas e vicissitudes da construção da memória social do regime militar brasileiro. Antíteses, Londrina, 2015.

${ }^{55}$ NOSSA, Leonencio. Busca de ossadas no Araguaia começa hoje. O Estado de São Paulo, São Paulo, 8. jul 1999. p. A12.
} 
Quanto a referida sumaumeira, ainda localizada na parte frontal do atual DNIT, é relatado em alguns depoimentos que os presos na Casa Azul teriam sido obrigados a dar voltas cantando em torno da centenária árvore. A utilização da música como instrumento de tortura é descrita, por exemplo, pelo já citado Manoel Messias Guido Ribeiro, que atuava no exército no período da Guerrilha:

Não eram os guardas, eles faziam, cantavam junto com o prisioneiro, colocava o prisioneiro para cantar, eles faziam era colocar o prisioneiro para cantar junto com ele. Não foi só na Casa Azul, isso aconteceu no quartel também. Lá no quartel mesmo aconteceu isto, no comando lá em cima aconteceu a mesma coisa, com a mesma música que é uma tortura, é horrivel, a gente também se sente torturado só em lembrar. Só em lembrar se sente torturado, porque você via tudo e não podia fazer nada, é aquele negócio, você está vendo um destruir o outro, matar o outro, assim você morre também, você fica vamos dizer assim, inerte. ${ }^{57}$

Em 2011, durante ação do GTA, foi colhido outro depoimento relacionado à Casa Azul, apresentado em diversos momentos do relatório da quarta expedição do grupo, realizada entre 23 de setembro e 4 de outubro daquele ano. Em um desses relatos, uma das integrantes do GT, Diva Soares Santana, irmã da guerrilheira Dinaelza Santana (Maria Dina), e representante no GT da Comissão Especial de Mortos e Desaparecidos Políticos (CEMDP), relata:

Marabá-PA, no dia 24 do mês em curso, visitamos o morador da cidade, Sr. Afonso, aposentado do Incra na função de motorista e na época da guerrilha, foi designado a servir, na mesma profissão, aos militares das Forças Armadas, transportando-os a diversas localidades da região.

Diante das informações prestadas pelo Sr. Afonso, fizemos contato com um exfuncionário do DNER, Sr. Ronaldo, também aposentado, que nos passou a seguinte informação: que já mais ou menos 20 anos após uma forte chuva, avistou uma grande cratera aberta, resultado da enxurrada, na área do pátio do DNER, atualmente Denit (sic.). A existência de um túnel naquela área já era do conhecimento dos trabalhadores do órgão e para atender a sua curiosidade se dirigiu ao início da cratera, percorreu até certo ponto e percebeu tratar-se de um buraco mais profundo, contendo paredes cobertas com madeira, tipo uma cerca, forradas com um plástico grosso $e$ grande quantidade de um produto parecido com cal.

Perplexo com a descoberta se retira do local e encontra um engenheiro do mesmo órgão que the pediu para não prosseguir, argumentando que aquele lugar era perigoso, contudo não entrou em detalhes. ${ }^{58}$

No ano de 2014, foi concluído o já referido relatório final da CNV, onde a Casa Azul novamente ganharia destaque. Antes da publicação do relatório final, porém, o espaço fora abordado pela mesma comissão no Relatório preliminar de pesquisa Centros clandestinos de violação de Direitos Humanos. Nesse relatório são apresentados nomes de vinte e quatro pessoas, entre uma maioria de guerrilheiros $e$ alguns camponeses, que teriam sido mortos no local. ${ }^{59}$

\footnotetext{
${ }^{56}$ NOSSA, Busca de ossadas..., p. A12.

57 Depoimento de Manoel Messias Guido Ribeiro, ACERVO CNV, 2014. Disponível em: http://cnv.memoriasreveladas.gov.br/todos-volume-1/658-documentos-sobre-a-guerrilha-do-araguaia.html, Acesso: 15 . Dez. 2016.

${ }^{58}$ MINISTÉRIO PÚBLICO FEDERAL. Grupo de Trabalho Araguaia. Disponível em: http://www.mpf.mp.br/atuacaotematica/ccr2/importacao/gt-justica-de-transicao/relatorios-1. Acesso: abr. 2017.

${ }^{59}$ José Lima Piauhy Dourado (Ivo); Divino Ferreira de Souza (Nunes), Demerval da Silva Pereira (João Araguaia), Cilon da Cunha Brum (Simão), Dinalva Oliveira Teixeira (Dina), Luiz René Silveira e Silva (Duda), Tobias Pereira Júnior (Josias),Dinaelza Soares Santana Coqueiro (Maria Dina)", Custódio Saraiva Neto (Lauro), Maria Célia Corrêa (Rosinha), Walquíria Afonso Costa (Vera), José Huberto Bronca (Fogoió), Roberto Pereira Marques (Amaury), Telma Regina Cordeiro Corrêa (Lia), Antônio Teodoro de Castro (Raul), Luiza Augusta Garlippe (Tuca), Daniel Ribeiro Callado (Doca), Lúcio Petit da Silva (Beto), Suely Yumiko Kanayama (Chica), Uirassu de Assis Batista (Valdir), Pedro Pereira de Souza (Carretel), Batista (Izaldo). BRASIL. Relatório preliminar de pesquisa Centros clandestinos..., p. 11.
} 
Em 2015, Thiesen e Almeida fizeram análise sobre as informações relacionadas à Casa Azul presentes no relatório final da $\mathrm{CNV}$ e questionaram se o local irá constituir-se como um futuro lugar de memória. ${ }^{60}$ No mesmo ano, a Universidade Federal do Sul e Sudeste do Pará (Unifesspa), criada em 2013 na região de abrangência da Guerrilha, com sede em Marabá, deu início a estudos, ainda em curso, que possibilitassem o tombamento do referido espaço, buscando o apoio da CEMDP para a criação de um espaço de memória relacionado à história da Guerrilha, da Ditadura e da luta em prol dos direitos humanos, levando-se em conta também a história da "guerra que veio depois" e os inúmeros legados deixados pela Guerrilha na região.

\section{Considerações finais}

As memórias sobre a Casa Azul encontram-se numa fase bastante dinâmica quando do período de finalização deste artigo, assim como ocorre com a própria memória da Guerrilha e da Ditadura, em perspectivas mais amplas, que continuam a ser colocadas em disputas, principalmente num contexto em que se reafirmam, sob novas roupagens, discursos autoritários legados da Ditadura Militar; bem como práticas de violência voltadas para os sujeitos do campo (vide o recente massacre de camponeses sem-terra por parte de policiais no município de Pau D’Arco, no Sul do Pará), populações pobres das periferias das grandes cidades do país (lembremos dos episódios mais fatídicos da atual ocupação militar no Rio de Janeiro; e eventos indiretamente a ela relacionados, como o assassinato da vereadora Marielle Franco, no início de 2018), ainda alvo de ações originadas de um legado autoritário.

Apesar de produzidas em momentos e suportes distintos, as fontes abordadas apontam para eventos relacionados à um dos principais centros clandestinos de aprisionamento existentes no Brasil durante a Ditadura. Testemunhos vários que, apesar dos enquadramentos dados pelos veículos, órgãos ou sujeitos responsáveis pela sua produção, apontam conjuntamente para um dos pontos centrais de atuação no país da malha de informações e da política repressiva organizadas pelo Estado brasileiro entre o final dos anos 1960 e início da década de 1970.

Não deixa de ser digno de nota que o reconhecimento oficial deste espaço pelo Estado, através do relatório final da CNV em 2014, tenha vindo em decorrência de condenação sofrida pelo Brasil após processo aberto pelos familiares de mortos e desaparecidos do Araguaia. E um olha atento para as fontes aqui trabalhadas, boa parte delas fora provocada direta ou indiretamente pela busca realizada por estes familiares, em especial através da CEMDP e sua inserção junto ao GTA e GTT.

Também vem sendo fundamentais as memórias dos camponeses, que inicialmente veicularam suas narrativas subterrâneas apenas às pessoas mais próximas, como a citação apresentada da obra $\mathrm{Pe}$. Ricardo Rezende; mas, com o passar do tempo, foram retirando do subterrâneo, ao menos em parte, uma parcela significativa de eventos pouco divulgados e seus pontos de vista sobre o que testemunharam durante o desenrolar da Guerrilha.

A existência dessas memórias dos camponeses, bem como a luta dos familiares, a todo o momento pressionado os diversos governos militares e da redemocratização por informações e políticas de reparação, contribuíram com a criação de um contexto onde mesmo os militares (oficiais, mas também cabos) que serviram às Forças Armadas durante o conflito, passariam a reivindicar um lugar nas memórias tidas sobre ele, após inicialmente abdicarem de contar o que sabiam sobre um evento em que saíram vencedores, mas cujos detalhes procuram manter ainda sob sete chaves, sobretudo aqueles que podem incriminar agentes da repressão que ainda se encontram com vida.

Desse modo, nas últimas quatro décadas, as memórias relacionadas à Casa Azul foram sendo desveladas, paulatinamente, por um terreno tortuoso, de memórias difíceis; bem como de estratégias de apagamento de rastros e de ações de contrainformação que continuam sendo colocadas em andamento, fazendo com que certas dimensões da Guerrilha (a exemplo da localização dos corpos dos guerrilheiros; bem como as batalhas da memória) não tenham chegado ainda ao seu final.

Tal adiamento, quase que perpétuo, de respostas sobre aquele episódio, contribuem para que a sociedade que o provocou avance pouco no sentido de superar os desrespeitos aos direitos humanos,

\footnotetext{
${ }^{60}$ THIESEN, Icléia; ALMEIDA, Priscila Cabral. Lugares de memória da ditadura e a patrimonialização da experiência política. Revista do programa de Pós-Graduação em Ciências da Informação da Universidade de Brasília. Disponível em: http://periodicos.unb.br/index.php/museologia/article/view/16795. Acesso: fev. 2017.
} 
bem como na luta contra a banalização da violência, da tortura e dos assassinatos, inclusive aqueles constantemente cometidos por agentes do estado, que acabam naturalizando as práticas de períodos em que seus antecessores ganharam carta branca para matar e cometer diversos outros tipos de atrocidades, permanecendo impunes até os dias atuais.

Tornar melhor conhecidos os episódios e a própria construção da memória sobre centros clandestinos de tortura como a Casa Azul poderá contribuir para a desnaturalização do atual quadro de violência vivido na região da Guerrilha e no País como um todo, apontando, quem sabe, para a construção de caminhos que não sejam voltados apenas à reprodução de práticas autoritárias — ainda que mantidas sob disfarce democrático mas para a construção de novos rumos, construídos também a partir do entendimento das experiências e erros cometidos no Araguaia. 


\section{RESUMO}

Entre 1972 e 1974, o Sudeste do Pará, assim como parte do Maranhão e do norte do atual Tocantins, foi palco da Guerrilha do Araguaia, conflito que marcou não somente a história recente do Brasil, como deixou diversas heranças para a região onde ocorrera, incluindo-se um legado autoritário marcado pela repressão a movimentos sociais voltados para a luta pela terra no contexto da redemocratização. Em Marabá-PA, fora montado durante a Guerrilha estrutura que visava combater os militantes do PCdoB em atuação na região, consistindo na formação de quartéis, bem como no uso de outros órgãos públicos no suporte as ações do Centro de Inteligência do Exército (CIE). Um desses órgãos fora o então denominado Departamento Nacional de Estradas de Rodagem (DNER), cuja sede fora apontada por camponeses e ex-soldados que por ali passaram como um centro de prisão clandestino, onde teriam ocorridos graves violações dos direitos humanos, que teriam atingido guerrilheiros e camponeses da região. Há relatos que apontam que alguns dos desaparecidos políticos no contexto da Guerrilha foram aprisionados, torturados, mortos ou vistos pela última vez no local, chamado à época de Casa Azul. Após o fim dos conflitos, a Casa Azul teria sido envolvida na Operação Limpeza, como é descrita a ação onde se efetivou o apagamento dos rastros sobre as violações perpetradas durante a Guerrilha por parte de agentes das Forças Armadas. $\mathrm{O}$ artigo se propõe a contextualizar o processo de desvelamento de memórias sobre o local, à revelia das estratégias de silenciamento que foram criadas pelos agentes da Ditadura em relação às violações ocorridas na Guerrilha do Araguaia; objetiva, através dos rastros deixados sobre a Casa Azul, colaborar para maior compreensão sobre um dos espaços marcantes no que concerne as estratégias repressivas adotadas durante o Regime Militar no Brasil.

Palavras chave: Guerrilha do Araguaia; Casa Azul; Sudeste do Pará.

Artigo recebido em 15 ago. 2018.

Aprovado em 07 set. 2018.

\section{ABSTRACT}

Between 1972 and 1974 the Southeast of Pará State - as well as part of the Maranhão State and the region currently located in the Tocantins State - was arena for the Araguaia Guerrilla, a conflict that not only marked the recent history of Brazil but also left several cultural marks in the region, among which an authoritarian legacy marked by repression of social movements seeking land distribution within the context of the post-dictatorship redemocratization. In the City of Marabá-PA a structure was set during the Guerrilla period aiming at fighting $\mathrm{PCdoB}$ [political party] militants present in the region, which consisted in the formation of military barracks and in the use of other public agencies to support the actions of the Military Intelligence Center (CIE). One of these public agencies was called National Department of Roads and Highways (DNER) at the time, which headquarters were reported by local farmers and former soldiers as being a clandestine prison where serious human rights violations would have occurred against guerilla members and local farmers. Some accounts mention that some of the people missing within the context of the Guerrilla had been imprisoned, tortured, killed or last seen in that location, at the time called the Blue House. After the end of the conflicts, the Blue House would have been involved in the Cleaning Operation, described as the deletion of information concerning the violations perpetrated during the Guerrilla period on the part of Armed Forces agents. This article intends to provide context for the process of unveiling memories of that place, despite the silencing strategies created by the Dictatorship agents concerning the violations occurred in the Araguaia Guerrilla period; it aims at contributing with a better understanding about some of the staggering repression strategies adopted during the Military Dictatorship in Brazil through the few traces left by its perpetrators related to the Blue House.

Keywords: Araguaia Guerrilla; Blue House; Southeast of Pará State. 
